\title{
The metaphysics of conflict: some reflections on Schopenhauer's politics
}

\author{
A metafísica do conflito: algumas reflexões sobre a política de \\ Schopenhauer
}

\author{
Davide Ruggieri \\ PhD Philosophy at the University of Salento \\ PhD Sociology at the University of Bologna \\ E-mail: davide.ruggieri3@unibo.it
}

\begin{abstract}
This paper argues for a new inter-pretation of Schopenhauer's political theory in the light of the category of conflict. Accor-ding to Schopenhauer's metaphysics, The Will (to live), that inhabits any living being and always requests Will/life, cannot ever grasp itself in the "representational" side. This generates struggle, conflict, misery and sorrow. This schismatic and conflictual schema recurs in his moral, social and poli-tical arguments. Coherently with his meta-physical view, he substantially theorized the socio-political issue twofold ("political Ma-nichaeism"). On the one hand is the repre-sentational sphere - politics as an institu-tional question (the regulative function of the State); on the other hand, the metaphy-sical or inner sphere - conflict (as means) is unavoidable and solidarity (as goal) in any human social, moral and political agency re-presents the one and only irremissible pres-criptive principle.
\end{abstract}

Palavras-chave: Schopenhauer; Metaphisics; Conflict; Political manichaeism.
Resumo: Este artigo defende uma nova interpretação da teoria política de Schopenhauer à luz da categoria de conflito. De acordo com a metafísica de Schopenhauer, o conceito de vontade (de vida), que habita todo ser vivo e sempre requer vontade e vida, não pode ser captado pelo lado "representacional"; isso geraria luta, conflito, miséria e tristeza. Esse esquema cindido e conflitante se repete nos temas morais, sociais e políticos do filósofo. Coerente com sua visão metafísica, Schopenhauer teorizou substancialmente a questão sócio-política a partir de uma dupla vertente (maniqueísmo político). Por um lado, tem-se a esfera representacional - política como uma questão institucional (a função regulativa do Estado). Por outro lado, a esfera metafísica ou interna - em que o conflito (como meio) é inevitável e a solidariedade (como meta), sob qualquer forma de agir moral, político e social, representa o único e irremissível princípio moral de tipo prescritivo.

Keywords: Schopenhauer; Metafísica; Conflito; Maniqueísmo político. 


\section{Schopenhauer and the category of conflict}

$\mathrm{I}$ n the title of my paper I use the terms "metaphysics" and "conflict" as the keywords to read Schopenhauer's Politics. The former is the framework to comprehend the various meanings of the latter: conflict, contradiction and disagreement are not merely human actions, but the core of metaphysical doctrine, which ethics and politics build on. So I will discuss this issue in two steps: 1) I will argue for the category of "conflict" in Schopenhauer's philosophy, then, 2) I will discuss the fundamental dichotomy in Schopenhauer's political theory (political Manichaeism).

Schopenhauer did not write any systematic treatise on legal-political doctrine in a strict sense. He was neither Kant, nor Fichte or Hegel: he did not take part in political debates or strongly point out the best policy for humankind. On the contrary, he experienced his "Zeitgeist" with a modern epicurean mood: $\Lambda \alpha \dot{\alpha} \theta \varepsilon$ $\beta \iota \omega ́ \sigma \alpha \varsigma$ (Epicurus), or with the Latin locution Bene vixit qui bene latuit (Ovid). Schopenhauer did not recognize himself in a Nation; he felt himself to be a citizen of a higher corpus politicus. In a letter sent to the Dean of the University of Jena in 1812 - after the Napoleonic siege of Berlin - he wrote that he felt like a stranger everywhere and all the time: he would not serve humankind by fighting with his hands, but by writing and thinking 1 .

Schopenhauer's political disengagement depends primarily on his private income: he could quickly and easily move away (around the whole European area) when he felt himself to be in peril or discomfort. This happened, for example, in 1806 when the Napoleonic troops broke into Weimar and particularly in 1848 when the revolutionary "sovereign canaille" upset Frankfurt. In a letter sent to Julius Frauenstaedt on 11 July 1848, Schopenhauer wrote: "When the storm comes, all the sails must be stricken"2. This political disengagement is also theoretically meaningful: it depends on Schopenhauer's “intransigent nominalism", so Max Horkheimer meant his socio-political attitude. In fact, Schopenhauer considered the State, Justice, Law, Society and History to be just names or abstractions,

${ }^{1}$ SCHOPENHAUER, A. Gesammelte Briefe, p. 643.

2 Idem, p. 231. 
standing for nothing real or existing 3 . Only the individual is "real"; this is the reason why he upheld this scepticism.

Nevertheless, he was not uninterested in political and historical events; he just literally kept his "distance" from them. From very early on, this was his conviction. As he noted in 1814 about society and humankind, it is necessary and wise to maintain "a distant behaviour" like a flame; the wise man gets warm while keeping his distance from it, whereas the stupid one complains that the flame burns. So let me get you into the core issue of my presentation

Consideration of Schopenhauer's political theory must not omit his metaphysical doctrine. He solved ethical and political questions through metaphysics, as testified in some letters ${ }^{5}$. In 1813, the young Schopenhauer already noted that his philosophy should be regarded as ethics and metaphysics together, two disciplines wrongly separated, in the same way that human beings are wrongly divided into body and mind 6 .

In the second book of The World as Will and Representation, Schopenhauer explains that the metaphysical feature of the whole world is conflictual.

Everywhere in nature - writes Schopenhauer - we see conflict, we see struggle, we see victory changing hands; later we will recognize this more clearly as the internal rupture that is essential to the Will. Each level of Will's objectification is in conflict with the others over matter, space and time ${ }^{7}$.

The inner nature of Will is an irrational and unitary principle, which objectifies itself gradually, and then Schopenhauer hypothesizes a hierarchic order for the world structure. Each grade is a platonic Idea, which is an eternal shape that occurs in the representation through space, time and causality. At the lowest grade of the objectification of Will, there are natural bio-chemical and physical forces; at

\footnotetext{
${ }^{3}$ Cf. HORKHEIMER, M. Gesammelte Schriften, p. 43; cf. SCHMIDT, A. Tugend und Weltlauf.

4 SCHOPENHAUER, A. Der handscrifltiche Nachlass, FM, p. 113.

${ }^{5}$ Cf. BRINKMANN, K. Die Rechts- und Staatslehre Schopenhauers, p. 10.

${ }^{6}$ Cf. SCHOPENHAUER, A. Der handscrifltliche Nachlass, FM, p. 55.

${ }^{7}$ I quote the original text: "So sehen wir in der Natur überall Streit, Kampf und Wechsel des Sieges, und werden eben darin weiterhin die dem Willen wesentliche Entzweiung mit sich selbst deutlicher erkennen. Jede Stufe der Objektivation des Willens macht der andern die Materie, den Raum, die Zeit streitig" (SCHOPENHAUER, A. WWV I, § 27, p. 208 [English translation of The World as Will and Representation refers to SCHOPENHAUER, A. 2010]).
} 
the top, in human beings, there is reason, which is not at all sovereign in nature, but simply and always enslaved to Will. Referring to Schopenhauer's Berlin Lessons, Sandro Barbera writes: "L’unité de la nature se présente comme une hiérarchie de forces (generals, mécaniques, chimiques, oeganiques, morales) qui sont toutes, à different niveaux, des objectivations de la volonté"8.

The universal forces in nature become real through polarization, divisions and oppositions. Kein Sieg ohne Kampf [No victory without a struggle $]^{9}$ : this is Schopenhauer's synthetic motto, dealing with all the conflictual dynamics and the continuous and natural struggle, which relates to many grades in the emanation of the Will to live.

Since the higher Idea or objectification of the Will - writes Schopenhauer - can come forward only by overpowering the lower Ideas, it encounters resistance on their part. Even when the lower Ideas are quickly brought, they nonetheless keep striving to express their essence in a complete and self-sufficient manner ${ }^{10}$.

Schopenhauer directly deduces from Schelling's doctrine the polarization in nature as the general principle, as the "original phenomenon", as unity structured in polarization: Barbera argues that Schopenhauer learned from Schelling the concept of "powers" in nature, which engage conflict to get a supreme unity ${ }^{11}$. Barbera writes: "Les forces supérieures sont les «puissances» (dans le sense mathématique du term) de celles inférieures, et tout la dinamique des forces est sostenue par le conflit qui en constitue le moteur et la référence commune"12. Again, in the fourth book of his masterpiece, Schopenhauer repeats that in each grade of the objectification of Will there is a steady struggle [ein beständiger Kampf] among individuals of every species, and this is the expression of an "intimate conflict of the Will to live against itself"13.

\footnotetext{
8 BARBERA, S. Une philosophie du conflit, p. 99.

${ }^{9}$ Cf. SCHOPENHAUER, A. WWV I, § 27, pp. 203-204.

10 "Indem die höhere Idee, oder Willensobjektivation, nur durch Überwältigung der niedrigeren hervortreten kann, erleidet sie den Widerstand dieser, welche, wenn gleich zur Dienstbarkeit gebracht, doch immer noch streben, zur unabhängigen und vollständigen Äußerung ihres Wesens zu gelangen" (SCHOPENHAUER, A. WWV I, § 27, p. 207).

${ }^{11}$ Cf. SCHOPENHAUER, A. Der handschriftilche Nachlass, FM, § 548; cf. BARBERA, S. Une philosophie du conflit, pp. 106-107.

${ }^{12}$ BARBERA, S. Une philosophie du conflit, pp. 101-102.

13 SCHOPENHAUER, A. WWV I, § 61, pp. 430-431.
} 
In this sense, there cannot be any "struggle for recognition" [Kampf um Anerkennung], as pointed out by Axel Honneth ${ }^{14}$. The conflictual issue does not deal in fact with consciousness and its instances, so that we can consider that political and multi-layered society derives from "ethical life" [Sittlichkeit]. Schopenhauer's theory of conflict is deeper than the Hegelian scheme of contradiction: Schopenhauer's model involves all living beings and the category of conflict explains the way the Will to live arises. It basically concerns a "metaphysical grammar" of the conflict, therefore it is possible to argue for the moral and socio-political sphere. Barbera argues:

Dans le conflit, qui suppose la présence de forces supérieures et de forces «résistantes», toutes les individualités sont manitenues et se reconnaissent réciproquement, sur l'example d'une dialectique valet (ou esclave)-maître, dans laquelle il est evident que le forces se modifient sur la base d'un modèle sociale. Schopenhauer parle de «domination» (Überwältigung) et de «résistance» (Widerstrand), et ce sont les même termes que Nietzsche emploiera pour indiquer le rapport commander-obéir qui constitue la structure profonde de la volonté de puissance, qu'il entend dans l'aphorisme 19 du Au-delà du bien et du mal et dans les fragmentes posthumes de la période comme un «affect du commandement» 15 .

Julius Bahnsen, one of the most original disciples of the "SchopenhauerSchule" (Fazio 2009a; 2009b), theorized a conflictual re-elaboration of Schopehauer's metaphysics, Realdialektik. In his work Der Widerpruch im Wissen und Wesen der Welt, published in 1880, he used the term and the concept of conflict to describe the metaphysical and internal contradiction of the Will, which is to be found among individuals and inside the individual ${ }^{16}$. Bahnsen argued for the "real negativity of the Will" and the core of his metaphysics is the self-contradictoriness of Will. He sustained that "the antithesis is the whole, whereas the thesis and the synthesis don't stand at all"17. The Realdialektik is the "science of the real contradiction": real is the self-parting of Will into "otherness", real are the individuals and their contradictions. Bahnsen theorized a strong theory of

\footnotetext{
${ }^{14} \mathrm{Cf}$. HONNETH, A. The struggle for recognition.

15 BARBERA, S. Une philosophie du conflit, p. 110.

16 Cf. BAHNSEN, J. Der Widerpruch im Wissen und Wesen der Welt, p. 48; p. 225.

17 BAHNSEN, J. Das Tragische als Weltgesetz und der Humor als ästhetische Gestalt des Metaphysischen, p. 1.
} 
contradictory dialectics without any kind of redemption (aesthetic or ethical). Schopenhauer on the contrary argued for a way to escape from conflict in nature or at least to catch it without suffering.

The struggle of material shapes in nature [Kampf der Formen um die Materie], described by Schopenhauer, is only an epiphenomenal aspect of Will in itself: it is the necessary mediation through the representational sphere. This order doesn't represent any plan of a higher entity: there is no teleological plan at all, since every part finds its raison d'être inwards, due to the fragmentary character of the world and life. He felt very close to Hölderlin's conviction in Hyperion about the coming of the spiritual night and the absence of Gods. Schopenhauer reversed the Western teleological perspective and theorizes the end of any rational and human

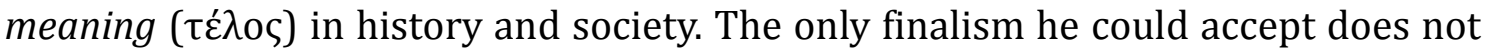
depend on human categories: so finalism is just the name of what we are able to grasp about the realization of Will.

However, in this hierarchic and complex order in nature, human beings find their place at the top: the human species is able to overwhelm the others and to submit nature as a whole. Nature is considered, in fact, as a "product at human disposal": this idea, very familiar to Heidegger and Jonas, is the key for Schopenhauer to explain that our natural disposition for struggle is reflected inside human nature. Human hegemony over the animal, plant and mineral kingdom becomes a hegemony over our neighbours: homo homini lupus, as Schopenhauer directly refers to Hobbes. The same contention and overwhelming in the lower grades of the objectification of Will recurs in human relations ${ }^{18}$.

For Schopenhauer, conflict between individuals is the most terrible in nature. In his masterpiece Schopenhauer writes: "At the highest level of consciousness, which is to say human consciousness, egoism (like cognition, pain and joy) must have reached the higher level as well, and the conflict between individuals (that it conditions) must be at its most terrible"19. Thus, Egoism is the

18 Cf. BARBERA, S. Une philosophie du conflit, pp. 103-104.

19 "In dem auf den höchsten Grad gesteigerten Bewußtseyn, dem menschlichen, muß die Erkenntniß, der Schmerz, die Freude, so auch der Egoismus den höchsten Grad erreicht haben und der durch ihn bedingte Widerstreit der Individuen auf das entsetzlichste hervortreten" (SCHOPENHAUER, A. WWV I, § 61, p. 432 [see also SCHOPENHAUER, A. On the basis of morality]). 
"starting point for all struggle" [Ausgangspunkt alles Kampfes] in human agency 20 and the real "longing to existence and well-being"21, as Schopenhauer affirms in On the basis of morality. It is the first fact of moral consciousness: "egoism is colossal, it towers above the world" (KS, $§ 14: 553)$. Anybody can recognize inwards the inner centre of the world (WWII, $§ 47: 698$ ), but looking outside we feel just like a "drop in the sea". The difference from the other is "absolute" (KS, § 22: 622). So, reason builds the State to prevent the consequences of universal egoism, which is then the first moral stimulus to fight through the real "cardinal virtue", that is justice [Gerechtigkeit]. In On the basis of morality, Schopenhauer writes: "In war we must first recognize the enemy; in the impending struggle, egoism, as the chief force on its own side, will be the principal opponent of the virtue of justice, which in my opinion is the first and really cardinal virtue" 22 .

The justice mentioned above is not providence and it is not related to human deeds in the course of history. If we expect to find a trail or a sign of a higher plan (rational, divine or simply finalist) in historical events, we're destined to fail. In Parerga und Paralipomena Schopenhauer argues about his philosophy of history. In a short and illuminating paragraph (Chapter 12), he says that:

History shows us the life of nations and we cannot find in it nothing but wars and outrage [Kriege und Empörungen]; the years of peace appear here and there only as short pauses, as intervals between the acts. And in the same way, the life of the individual is a perpetual struggle, not merely metaphorically with want and boredom but actually with others. Everywhere he finds an opponent, lives in constant conflict, and dies weapon in hand ${ }^{23}$.

This is Schopenhauer's statement, which he previously noted in 1822 in his

\footnotetext{
20 Cf. SCHOPENHAUER, A. WWV I, § 61, p. 431.

21 “[...] der Drang zum Daseyn und Wohlseyn” (SCHOPENHAUER, A. Werke in fünf Bände, KS, § 14, p. 552).

22 "Inzwischen ist im Kriege das Erste, daß man den Feind rekognoscirt. In dem bevorstehenden Kampfe wird der Egoismus, als der Hauptmacht seiner Seite, vorzüglich sich der Tugend der Gerechtigkeit entgegengestellen, welche, nach meiner Ansicht, die erste und recht eigentliche Kardinaltugend ist" (idem, KS, § 14, p. 555).

23 "Die Geschichte zeigt uns das Leben der Völker, und findet nichts als Kriege und Empörungen zu erzählen: die friedlichen Jahre erscheinen nur als kurze Pausen, Zwischenakte, dann und wann ein Mal. Und eben so ist das Leben des Einzelnen ein fortwährender Kampf, nicht etwan bloß metaphorisch mit der Noth, oder mit der Langenweile; sondern auch wirklich mit Andern. Er findet überall den Widersacher, lebt in beständigem Kämpfe und stirbt, die Waffen in der Hand" (SCHOPENHAUER, A. Werke in fünf Bände, PP II, p. 265).
} 
Berliner Manuscripts, explicitly citing Voltaire ${ }^{24}$.

Human nature reflects the intimate core and essence of the Will to live: we learn from history that progress is a useful illusion for human facts, which are characterized by blood and wars. According to Schopenhauer, we pay very dearly for our welfare. The argument of the "original Sin" in Schopenhauer deals with the idea that the joys of humankind are paid for through countless pains and sorrows. Justice through injustice; peace through war; good through evil. We should be aware of the fact that we are guilty; that is, we are part of a "collective" $\sin ^{25}$. The inequality in modern society is the product of a struggle between those few who use violence or cunning as means to prevail, and those who suffer this condition: Schopenhauer explicitly refers to proletarianism, poverty and slavery. "The whole unnatural condition of society", he says, [is] "the universal struggle to escape from misery" and he considered the diminishing of luxury, or even the abolishment of it altogether as the most effective way to alleviate human misery ${ }^{26}$.

\section{Schopenhauer and the flourishing politics from the metaphysics of Will}

\begin{tabular}{|l|l|}
\hline \multicolumn{1}{|c|}{ The World as Will } & \multicolumn{1}{c|}{ The World as Representation } \\
\hline $\begin{array}{l}\text { The Political (socio-moral agency through } \\
\text { conflictual/sympathetic participation) }\end{array}$ & $\begin{array}{l}\text { The Politics as Polity (the State with regulative } \\
\text { function) }\end{array}$ \\
\hline Metaphysical perspective & Subjective perspective \\
\hline Active Sphere/Agency & Passive Sphere/patire \\
\hline Conflict & Negotiation/Regulation \\
\hline Liberty & Necessity \\
\hline Eternal Justice & Temporal Justice \\
\hline
\end{tabular}

As the world is the result of an eternal contradiction due to its twofold configuration, I suggest we consider Schopenhauer's political theory by observing this metaphysical schema: the representational side (phenomenal, symbolic, illusionary) that concerns the world as it appears; and the metaphysical one (noumenical, substantial, real) that concerns the world as it is. We can count in fact a twofold political discourse in Schopenhauer: I call it "political Manichaeism". It is not intended as a struggle between Good and Evil; rather, it is a metaphor to

${ }^{24}$ Cf. SCHOPENHAUER, A. Der handschriftliche Nachlass, BM, § 122.

25 Cf. HORKHEIMER, M. Gesellschaft im Übergang, pp. 167-168.

26 Cf. SCHOPENHAUER, A. Werke in fünf Bände, PP II, § 125, pp. 223-224. 
identify an irreducible dichotomy between two levels in his political theory. I put forward the distinction between politics as representation and politics as will: this distinction refers to a widely shared opinion in contemporary political philosophy 27 about the difference between "politics" and "political". I refer particularly to Lefort's paradigm and to the distinction between the symbolic and normative sphere of the "politics" (la politique) and the essential and transnormative one of the "political"(le politique).

On the one hand, Schopenhauer recognizes that conflict is the core of any moral, social and authentic political agency (that is the political); on the other hand, he sustains the necessity of a monarchic political body (that is the polity) to naturally sedate pluralistic conflict, then to neutralize conflictual instances. In the '40s he proved himself very sceptical about revolutionary and democratic movements: looking at the political events in France in 1848, he explicitly felt much closer to Napoleon III than to the revolutionary crowd.

Schopenhauer's political theory is grounded in moral issues and branches out into a philosophy of law and a theory of justice. In his Dresden manuscripts, he explicitly wrote that the "concept of the Right is properly moral" and it literally means: the property of an individual Will - in its phenomenal appearance - to not deny the Will in other bodies ${ }^{28}$. The individual is damaging when their own affirmation is the negation of another "embedded" Will. He considers the Right theory as a "moral upside down". The question deals with "doing of wrong to someone" or "suffering of wrong by others": in other words, to cause and to suffer sorrow. Political institutions are born to remedy the second instance, that is, protecting individuals from their "suffering of wrong by others"29. This concept is remarked on by Schopenhauer in The World as Will and Representation, when he sustains that "suffering injustice" [das Unrechtleiden] refers to the "the conflict of the Will to live with itself, resulting from the plurality of individuals and egoism" 30 . The origin of the "social contract", that is the law, deals with renouncing to egoistic pleasure in causing injustice. In the Republic of Plato, Schopenhauer finds this first

27 Cf. LEFORT, C. Democracy and political Theory; cf. MOUFFE, C. Deliberative democracy and agonistic pluralism; cf. MACHART, 0. Post-foundational political thought; cf. HABERMAS, J. The "political".

28 Cf. SCHOPENHAUER, A. Der handschriftliche Nachlass, FM, § 535.

29 SCHOPENHAUER, A. Der handschriftliche Nachlass, FM, § 567.

30 SCHOPENHAUER, A. WWV I, § 62, p. 444. 
political postulate, much before Hobbes, Spinoza and Rousseau. "Schopenhauer sees the realization of the purpose of the state (the well-being of everyone) only in the negative, that is to say as an institute that guarantees protection" 31 .

If the first fundamental instance deals with suffering injustice, the second deals with committing it: so Schopenhauer argues for a "criminal" code as strategic means to deter crime, violence and injustice. It can be realized only inside the State, as right to punish [Strafrecht] in a "positive law"32.

The principal aims of the State are:

a. First of all, protection directed outwards; it deals with protection against the natural forces. This is the international legitimation of natural law.

b. Protection directed inwards; that is, protection of the members of the State against one another, and consequently the safeguarding of private law. But the granting of this twofold protection brings about the need for a third.

c. Protection against the protector, and thus a guarantee of civil law. It is necessary to keep the division of power into three, that is, legislative, executive and jurisdictional ${ }^{33}$.

The State (polity) is then a protective institution primarily against the "consequences of egoism", then against the "consequences of other people's egoism", as Schopenhauer noted in his early manuscripts ${ }^{34}$.

The politics is a particular kind of art; that is, managing the original nature of our essence: according to Schopenhauer, the authentic state of nature is characterized by "force" and "might" [Gewalt] ${ }^{35}$, then polity substitutes might with law through the legitimation in a new employment of it. The primary task of polity is to submit and then enslave physical might to intellect. Rationality is then the new name of that which governs above disorder and plurality. The most inner disposition of human nature is, in fact, the intellect and rationality, the "head" that leads our body. It is useful maybe to recall the original cover of Hobbes' Leviathan, where the monarch is represented as the head of a plurality of persons. Schopenhauer in Parerga und Paralipomena holds that, because of our

${ }^{31}$ GODART-VAN DER KROON, A. Schopenhauer's Theory of Justice and its Implication to Natural Law.

${ }^{32}$ SCHOPENHAUER, A. WWV I, § 62, p. 450.

${ }^{33}$ SCHOPENHAUER, A. WWV II, § 47, pp. 691-692.

${ }^{34}$ SCHOPENHAUER, A. Der handschriftliche Nachlass, JM, § 535.

35 "Von Natur herrscht die Gewalt: statt dieser dem Rechte zur Herrschaft zu verhelfen, dies ist das Problem der Staatkunst" (SCHOPENHAUER, A. Werke in fünf Bände, PP II, § 127, p. 227). 
"intellectual" nature, the best natural polity for humankind should be constitutional monarchy. Schopenhauer argues that the people are sovereign, but they must be under constant protection because of their minority ${ }^{36}$. The monarch corresponds to our brain, which leads and governs the parts of our body: so he affirms, using the Greek language, that the brain is literally $\eta \gamma \varepsilon \mu$ ovıкоv. According to Schopenhauer, the planetary system is "monarchic" too.

Schopenhauer's political Manichaeism cannot escape from selfcontradiction: the sphere of polity fills the symbolic space of politics through hegemony and might; that is, through the same forces and means it claims to fight in a moral sense. Thus, it contains, condemns and neutralizes conflict, which is the natural, metaphysical issue in human deeds. This brings us to Laclau's assertion in Emancipation(s): "universal is no more than a particular that at some moment has become dominant" 37.

However, for Schopenhauer the State cannot be the condition of liberty in the moral sense ${ }^{38}$ on the contrary to Hegel's feature. Schopenhauer criticizes Kant's doctrine too, since he derived the institution of the State as moral duty from the categorical imperative. As Schopenhauer says: "The State is set up in the correct assumption that pure morality (that is, correct conduct on moral grounds), is not to be expected; otherwise it would be superfluous"39. "Real" liberty is beyond phenomenon and representation, and this holds a fortiori beyond every human institution ${ }^{40}$.

In the chapter Zur Rechtslehre und Politik of Parerga und Paralipomena, Schopenhauer states his negative political model: he argues again that Rights, justice and liberty are negative concepts, whereas injustice, on the contrary, is positive ${ }^{41}$. His foundation of morality has a negative connotation too: Naeminem laede, imo omnes, quantum potes, iuva. In the third part of On the basis of Morality, Schopenhauer explains this idea. We perceive the multiplicity of the world, but we should go beyond it, because the "principle of individuation" is theoretically an

\footnotetext{
${ }^{36}$ Cf. SCHOPENHAUER, A. PP II, § 126, p. 226.

${ }^{37}$ LACLAU, E. Emancipation(s), p. 26.

${ }^{38}$ Cf. GODART-VAN DER KROON, A. Schopenhauer's Theory of Justice and its Implication to Natural Law.

39 "[Der Staat] errichtet unter der richtigen Voraussetzung, daß reine Moralität, d.h. Rechthandeln aus moralischen Gründen, nicht zu erwarten ist; außerdem er selbst ja überflüssig wäre".

${ }^{40}$ Cf. SCHOPENHAUER, A. WWV I, § 62, p. 448.

${ }^{41}$ Cf. SCHOPENHAUER, A. Werke in fünf Bände, PP II, § 121, p. 219.
} 
illusion. There is no real difference between individuals or living beings.

The paradox is that the real realization of the authentic political in moral sense always aims at the extra-politics; that is, overcoming the representational side. It is really close to an utopian spirit. The only authentic moral principle that can be followed is in fact solidarity, compassion [Mitleid], which is beyond any kind of individualism and egoism, then any struggle too. The individual must renounce their individuality.

Schopenhauer considered the core of his theory of Justice as a great "mystery": it deals with the concept of "compassion" [Mitleid]. It is the capacity to identify with another's suffering, with the aim of nullifying it. If the individual is able to neutralize the difference from the others, that is, he can go beyond the "representational" sphere, he grasps the "basis of any spontaneous and free justice and any genuine love for humankind" 42 . This is the only real basis, which can be considered as value of morality. Solidarity is, in fact, as Schopenhauer says, "the only source of non-egoistic agency, which has the right to be a moral value" 43 .

Compassion is then the moral key to gain access to "eternal Justice": Schopenhauer divided it from "temporal Justice", which finds a place only within the State and "can repay or punish the crime" through human institutions and time. Eternal Justice is still beyond them, because it goes beyond the principium individuationis: if we look, in fact, into the essence of the World, we are able to bear any suffering, injustice, abuse and offence, because we feel that they are moved against our own ${ }^{44}$. He who elevates above space, time and causality is able to grasp that the tormenter and the tormented are one. The theory of justice in Schopenhauer turns into mysticism. He finds in fact in the Upanishad precept of "Tat twam asi" ("You are that") the ethical and legal solution for egoism and individualism.

In conclusion, the only way to overcome the dichotomy between conflict and identification with others is to accept it. It is irreducible. The aim of good for the community might be realized only in this conflictual dialectics in the representational sphere. On the one hand, conflict, struggle, competition and

\footnotetext{
${ }^{42}$ SCHOPENHAUER, A. Werke in fünf Bände, KS, § 17, p. 565.

${ }^{43}$ Idem, KS, § 22, p. 621.

${ }^{44}$ Cf. SCHOPENHAUER, A. WWV I, § 63, pp. 456-457.
} 
difference are necessary and unavoidable; on the other hand, solidarity and compassion are desirable and pursuable. It is then possible to draft a new "recognition political theory" based on this dichotomy. The meaning of recognition deals first with the acceptance of the human metaphysical condition; that is, finiteness and misery. "A good conscience comes from the fact that unselfish deeds, arising out of the immediate recognition of our own essence in other appearances, confirm the recognition that our true self does not exist in the single appearance of our own person, but in every living thing" 45 .

We can accept then the recognition conception as a "transcendental condition" in the moral and political sphere, as Axel Honneth sustains in his social theory. But with Schopenhauer we learn more: recognition is also the "immanent condition", because of the reflecting logic between the Self and other living beings. Thus, Schopenhauer uses the verb wiedererkennen to mean "recognize" the same essence into other appearance. It is not simply an Anerkennung, which is literally legitimation-through-recognition into a normative paradigm. I would translate and understand Schopenhauer's Wiedererkennen as identifying-once-again the other in myself and myself in another. It is very similar to the aesthetical experience described by Schopenhauer. As the pure subject of knowledge stands in front of and reflects on the eternal shape of the Will (the Idea), so the Ego should completely fade away into other, forgetting its individuality: that is, becoming a pure subject in front of another pure subject (to paraphrase a well-known quotation in The World as Will and Representation).

\section{Bibliographical references}

BAHNSEN, Julius. Das Tragische als Weltgesetz und der Humor als ästhetische Gestalt des Metaphysischen. Lauenburg, 1877; now in Das Tragische als Weltgesetz und der Humor als ästhetische Gestalt des Metaphysischen. hrsg. von W.Müller-Seyfarth. Berlin: VanBremen VerlagsBuchhandlung, 1995.

Der Widerpruch im Wissen und Wesen der Welt. Princip und Einzelbewährung der Realdialektik, 2 vol. Leipzig, 1882.

\footnotetext{
45 "[Das gute Gewissen] entspringt daraus, daß solche That, wie sie hervorgeht aus dem unmittebaren Wiedererkennen unseres eigenen Wesens an sich auch in der fremden Erscheinung, uns auch wiederum die Beglaubigung dieser Erkenntniß giebt, der Erkenntniß, daß unser wahres Selbst nicht bloß in der eigenen Person, dieser einzelnen Erscheinung, da ist, sondern in Allem was lebt" (SCHOPENHAUER, A. WWV I, § 66, pp. 481-482).
} 
BARBERA, Sandro. Une philosophie du conflit. Études sur Schopenhauer. Paris: PUF, 2004.

BRINKMANN, Karl. Die Rechts- und Staatslehre Schopenhauers. Bonn: E. van Hippel, 1958.

FAZIO, Domenico M. La Scuola di Schopenhauer: testi e contesti. Lecce: Pensa MultiMedia, 2009a («Schopenhaueriana», 2).

Die "Schopenhauer-Schule". Zur Geschichte eines Begriffs. In: Schopenhauer und die Schopenhauer-Schule. Beiträge zur Philosophie Schopenhauers. hrsg. von D. Fazio, M. Koßler, F. Ciracì. Würzburg: Königshausen \& Neumann, 2009b, pp. 15-41.

GODART-VAN DER KROON, Annette. Schopenhauer's Theory of Justice and its Implication to Natural Law. Jahrbuch der Schopenhauer-Gesellschaft, vol. 84, 2003, pp. 121-146.

HABERMAS, Jürgen. "The Political". The rational meaning of a questionable inheritance of political Theology, in The Power of Religion in the public Sphere. ed. by J. Butler, J. Habermas et al. New York: Columbia University Press, 2011, pp. 15-33.

HONNETH, Axel. The struggle for recognition. The moral grammar of social conflicts. Cambridge/London: MIT Press, 1996.

HORKHEIMER, Max. Gesellschaft im Übergang: Aufsätze, Reden und Vorträge 1942-1970. Hrsg. von W. Brede. Frankfurt: Athenäum-Fischer Verlag, 1972.

. Schopenhauer und die Gesellschaft (1955). In: Vorträge und Aufzeichningen 19491973, Gesammelte Schriften, Bd. 7. Hrsg. von G. Schmid Noerr. Frankfurt: Fischer Verlag, 1985.

LACLAU, Ernesto. Emancipation(s). New York: Verso, 1996.

LEFORT, Claude. Democracy and Politcal Theory. University of Minnesota Press 1989.

LÜTKEHAUS, Ludger. Die Ausfahrt des Buddha? Die Reisetagebüchers Schopenhauers. Jahrbuch der Schopenhauer-Gesellschaft, vol. 69, 1988, p. 615-626.

MACHART, Oliver. Post-foundational political thought: political difference in Nancy, Lefort, Badiou and Laclau. Edinburgh: Edinburgh University Press, 2007.

MOUFFE, Chantal. Deliberative democracy and Agonistic Pluralism. Wien: Institüt für Höhere Studien (IHS), 2000 («Reihe Politikwissenschaft», 72). (https://www.ihs.ac.at/publications/pol/pw_72.pdf). . On the Political. New York: Routledge, 2005.

NIETZSCHE, Friedrich. Jenseits von Gut und Böse. Vorspiel einer Philosophie der Zukunft. Leipzig: Druck und Verlag von C. G. Naumann, 1886 (eKGWB: www.nietzschesource.org, 2009).

SCHMIDT, Alfred. Tugend und Weltlauf. Vorträge und Aufsätze über die Philosophie Schopenhauers (1960-2003). Frankfurt: Peter Lang, 2004. 
SCHOPENHAUER, Arthur. Reisetagebücher aus den Jahren 1803bis 1804. Hrsg. von Ch. Von Gwinner. Leipzig: Brockhaus, 1923.

__. Gesammelte Briefe. Hrsg. von A. Hübscher, Bonn: Bouvier, 1978.

1985:

Der handschriftliche Nachlass. Hrsg. von A. Hübscher. München: DTV [1966-1975],

I. Fruhe Manuskripte (1804-1818). [FM]

II. Kritische Auseinandersetzungen (1809-1818). [KA]

III. Berliner Manuskripte (1818-1830). [BM]

IV.1. Die Manuskriptbucher der Jahre 1830 bis 1852. [JM]

IV.2. Letzte Manuskripte; Gracians Handorakel. [LM]

V. Randschrifter zu Buchern.

. On the Basis of Morality. Cambridge: Hackett Publishing Company, 1995.

Werke in fünf Bände. Hrsg. von L. Lütkehaus. Zürich: Haffmans Verlag, 1999.

I. Die Welt als Wille und Vorstellung I [WWV I]

II. Die Welt als Wille und Vorselltung II [WWV II]

III. Kleinere Schriften [KS]

IV. Parerga und Paralipomena I [PP I]

V. Parerga und Paralipomena II [PP II]

Parerga and Paralipomena. 2 voll. Cambridge: Cambridge University Press, 2000.

2010

The World as Will and Representation. Cambridge: Cambridge University Press,

Recebido: 22/12/15

Received: $12 / 22 / 15$

Aprovado: $30 / 03 / 16$

Approved: 03/30/16 